\title{
O silêncio do delator: um inventário de perdas
}

\section{Nleilton Fonseca, UEF'}

\author{
Criar é nosso júbilo. \\ Entre risos e rugas \\ Morrer é nossa vitória. \\ Pedro Paulo de Sena Madureira
}

$O$ silêncio do delator, romance de José Nêumanne Pinto (São Paulo: A Girafa, 2004, 541 pág.) ganhou um dos mais importantes láureas do Brasil, o Prêmio Senador José Ermírio de Moraes 2005, da Academia Brasileira de Letras. O escritor, poeta e jornalista nascido no estado da Paraíba (1951) e radicado em São Paulo há vários anos, obteve o reconhecimento dos críticos e acadêmicos por haver escrito um livro que conjuga ficção e história, através de um estilo narrativo que informa, desafia e encanta o leitor, levando-o a refletir sobre o panorama político-social do País. O romance de Nêumanne retoma a linha ficcional do inventário político-ideológico da geração 60, no Brasil, que enfrentou a ditadura militar (1964-1985), respirou a arte pop e o cinema, embalou-se no rock-and-roll e na MPB, apoiou as barricadas estudantis parisienses e adotou os comportamentos da contracultura. Seus integrantes andam agora pela casa dos sessenta anos e vêm sofrendo suas baixas, trocando os antigos encontros nos bares pelos papos rememorativos em velórios de companheiros. Trata-se de uma turma que tem história em comum, sobretudo de resistência durante as décadas de 60-70, quando, em plena juventude, viveu o paradoxo de ser, internacionalmente, a geração dos Beatles, de Woodstock, das barricadas da Sorbonne, e, no Brasil, a geração podada, vigiada e perseguida pela repressão dos governos militares. Coube ao grupo mais intelectualizado dessa geração, - jornalistas, escritores, artistas, professores, militantes políticos -, escrever, discutir e viver a memória daquela época ao mesmo tempo rica, confusa e conturbada.

De fato, durante a década de oitenta, a partir da abertura política, as livrarias foram inundadas por dezenas de livros de depoimentos, relatos, poesia e ficção, escritos por autores oriundos dos grupos que sofreram as agruras dos anos de chumbo da ditadura militar. Havia muitos fatos e ações a revelar e a exorcizar, e os leitores estavam ansiosos para saber o que de fato se passava no País governado pelos generais. Em sua grande maioria, os títulos então lançados eram narrativas de denúncia, heróicas, idealistas e/ou ressentidas, que, embora bem escritas, não atingiam aquele nível de permanência inerente à obra de arte. Quase todos caíram em relativo esquecimento. Mesmo o livro $O$ que é isso companheiro? (1979), de Fernando Gabeira, que foi transformado em filme, não se firmou como grande obra literária. Enfim, nenhum deles conse- 
guiu se tornar o livro definitivo daquela geração que, em alguns casos, pegou em armas para lutar pelo país de seus sonhos e ideais. Talvez tenha faltado àqueles autores algo mais que a experiência vivida ou testemunhada: a capacidade de síntese e de generalização para escrever de modo menos heróico, menos auto-referencial e mais analítico, relativizando suas convicções, discutindo as limitações e a precariedade dos grupos, além de fazer autocrítica de suas veleidades libertárias e intelectuais. Nota-se, em geral, que a objetividade do depoimento, os compromissos ideológicos, a intenção política, a autocomiseração e a falta de distanciamento histórico limitaram a liberdade de criação, inibindo a intervenção da instância ficcional que poderia dar o tempero da prosa, levando-a a extrapolar os fatos e dar contornos mais profundos e persuasivos aos discursos dos protagonistas - ou antagonistas? -, dos anos 60-70 em nosso País.

Eis então que aparece, em 2004, O silêncio do delator, longa narrativa que conta a história de João Miguel, um morto que fala sem peias durante todo o seu velório. Corpo exposto diante de parentes e amigos, João Miguel se faz ouvir apenas pelo narrador principal. Só o narrador tem acesso à consciência do defunto e inscreve sua fala no tecido ficcional. $\mathrm{Na}$ condição de morto, João Miguel promete esclarecer a sua história e revelar os segredos de seus companheiros de trajetória: “Tudo o que estiver ao meu alcance será revelado neste velório. (...) Tudo o que sei, o que intuí. Tudo o que desconfiei. Agora que sou pó, que voltei à cinza, mas não voltarei à luz, pois fui gente e não fênix, me disponho a abrir o jogo, a mostrar as cartas, a peruar o baralho alheio. Agora, sim, posso falar de nosso malogro.” (p. 11-12). Será este o romance que faltava?
José Nêumanne Pinto, jornalista, poeta e ficcionista, com outros oito livros editados, distancia-se, conscientemente, do modelo até aqui seguido pela maioria dos autores dessa temática. De saída, Nêumanne adota uma estratégia francamente ficcional, ao dar o poder de fala a um morto, em pleno velório, fazendo-o dialogar com o narrador principal, espécie de moderador dos diversos discursos que contracenam ao longo do enredo. Ora, essa aplicação contemporânea do célebre procedimento machadiano, em Memórias póstumas de Brás Cubas (1881), surte um excelente efeito como elemento operatório da narrativa, abrindo espaço para discursos desabusados, versões e contradições, reflexões político-sociológicas e, sobretudo, observações metanarrativas. São divertidas e pertinentes as intromissões do morto na escrita do romance, ao fazer reparos e comentários jocosos e analisar detalhes, criticando a técnica do narrador principal, bem como ironizando o próprio autor.

O principal êxito da rede discursiva polifônica, em que várias vozes contracenam, é potencializar os recursos da ironia. Aqui a ironia e a auto-ironia dão tempero ao relato, pois permitem a relativização das verdades, dos ideais, das crenças, dos comportamentos, das ações individuais e coletivas. Com isso, evita-se o moralismo que muitas vezes acompanha a análise do comportamento de personagens militantes em causas políticas. Neste romance, tudo se discute e se relativiza, num processo que humaniza a trajetória das personagens. Elas não compõem uma legião de heróis e sacrificados, pois mantêm um perfil humano, falíveis, cônscios de seus erros, equívocos e acertos, êxitos e perdas. Os pretensos heróis da resistência político-cultural dos anos 60-70 riem de si mesmo e de suas fraquezas e limitações, um riso angustiado, com uma iro- 
nia tragicômica, mas que compõe um quadro realista, sem idealizações anacrônicas.

Em certo sentido, João Miguel simboliza, em seu velório, o alter-ego coletivo. Nele e com ele, estão mortos os ideais de sua geração. O narrador principal, cujo discurso é muitas vezes ironizado e contraditado pelo falecido, é a outra face deste alter-ego coletivo. Se o narrador-vivo ainda tenta contemporizar com algumas idéias e situações, como portador dos restos de esperança do grupo, o morto, despido de qualquer chance de ação, é portador das avaliações mais ferinas, um verdadeiro antídoto da má-consciência que, inadvertidamente, pode persistir nos discursos e atitudes dos demais, ainda comprometidos com as etiquetas e os interesses da vida. Entre os vivos, pode ainda haver os fiéis aos velhos ideais, como se fossem os únicos corretos e possíveis. Nas revelações e reflexões do narrador-morto, fica claro que se tratava de uma visão de mundo de um grupo, cuja adoção como verdade absoluta foi uma das causas dos equívocos e do malogro coletivo. Assim, o romance é um inventário de perdas: da inocência, da crença, do ideal, da certeza e, por tudo isso, a única vitória possível é morrer. A morte é a contribuição individual, de cada qual a seu tempo, permitindo aos companheiros as reflexões e autocríticas necessárias para compreender as grandezas e misérias de toda uma geração.

Em $O$ silêncio do delator, a alternância do foco narrativo é fundamental, pois cadencia a trama e equilibra o pêndulo entre a realidade e a ficção. O diálogo tenso, irônico e arrevesado dos narradores, o vivo e o morto, proporciona um debate duro e esclarecedor, tra- ça o perfil ideológico e existencial das personagens, entremostra seus acertos e equívocos, perdas e ganhos, inconseqüências, veleidades e contradições. Avessos às políticas do mercado, inimigos da razão capitalista e autoritária, portadores da consciência crítica, sua contribuição havia mesmo de ser a produção de discursos: no jornalismo, nas artes, na literatura, no ensino universitário - seus fronts de combate ideológico. Na grande arena, os inimigos: a média burguesia urbana e letrada contra a alta burguesia industrial-financeira, visceralmente imiscuída no poder. Uma luta de titãs. As personagens de Nêumanne persignam-se sobre o morto, - símbolo de suas derrotas. Um morto que, no entanto, não se cala. A morte expõe sua trajetória ao lado dos companheiros, - e o seu silêncio delata o grande teatro vivido coletivamente. Eis o inventário de uma geração vitoriosa na derrota, à qual cabe como epitáfio o poema de Pedro Paulo de Sena Madureira, que aparece ao final do livro.

O silêncio do delator é um grande romance. Pela forma, pela linguagem, pela tática narrativa, pelo dialogismo dinâmico, ele dramatiza os relatos e atinge a qualidade literária, pois adota, com acerto, os procedimentos ficcionais que dão relevo aos fatos da realidade, elevando-os a um nível de complexidade e de significação para além dos registros documentais e jornalísticos. Trata-se de uma narrativa amarga e pessimista, paradoxalmente escrita com ironia e humor desabusado, que radiografa a atmosfera dos anos 60-70, desnudando a alma de uma geração que viveu intensamente seus ideais e suas frustrações, deixando marcas na história social e na cultura brasileira do século XX.

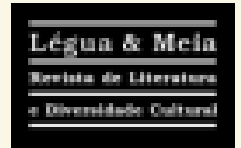

FONSECA, Aleiilton. O Silêncio do delator: um inventário de perdas. Légua \& meia: Revista de literatura e diversidade cultural. Feira de Santana: UEFS, v. 4, n 3, 2005, p. 269-271. 